\title{
Den Ene og den Andre
}

\section{Betraktninger om forskningsbaserte stillbilder av kjønnsforskjeller og andre forskjeller i skolen}

\author{
Av Birgit Nordtug, Benedikte Thaulow og Gunn Engelsrud
}

I artikkelen setter forfatterne et kritisk søkelys på forskning og politikk der gutter og jenter blir forstått på gruppenivå. Sarlig kommer gruppetenkning fram i evidensbasert forskning om kjønnsforskjeller $i$ skolen. Ved å bruke biologiske forskjeller som forklaring, hevdes det at gutter får dårligere karakterer enn jenter, mens jenter opplever mer stress og press enn gutter. Når politikk og praksis forankres i denne typen forskning, kan det bidra til at gutter og jenter fikseres $i$ et statisk enten-eller-forhold. Både variasjoner innad $i$ gruppene og individuelle erfaringer risikerer herved å bli usynlige og ugyldige. Det gjelder også andre forskningsbaserte stillbilder som kun åpner for å ta posisjonen som enten den Ene eller den Andre. Forfatterne eksemplifiserer det med analyser av klasseforskjeller og loerer-elev-forholdet. Med utgangspunkt i Dag Østerbergs klassiske essay Forståelsesformer undersøker forfatterne hva slags forståelser en slik statisk gruppetenkning er basert på. Det tas til orde for å anse gutter og jenter og andre grupper som både forskjellige og like, som personer som deltar sammen $i$ skolen og som larer av hverandre.

\section{BIRGIT NoRDTUG, førsteamanuensis i psykologi ved Hogskolen i Innlandet, e-post: birgit.nordtug@inn.no \\ BenEDIKTE Thaulow, lektor i spesialpedagogikk ved Ringerike Steinerskole, e-post: benedikte.thaulow@gmail.com \\ GuNN ENGELSRUD, professor $i$ idrettsvitenskap ved Hogskulen på Vestlandet, e-post: Gunn.Helene.Engelsrud@hvl.no}

«Jenter har fått bedre karakterer enn gutter i minst et halvt århundre», skriver sosiologen og kjønnsforskeren Kristoffer Chelsom Vogt (2019: 178). Det er imidlertid først i de senere årene at denne forskjellen har fått mye oppmerksomhet, og på en slik måte at det har blitt en svartmaling av gutter, påpeker han. Pedagogikkprofessorene Herner Sæverot og Glenn-Egil Torgersen (2019) istemmer. De hevder at guttene blir satt i skolens skammekrok når deres dårligere karakterer ensidig forklares ut fra biologiske forhold. Mediene har vært flittige formidlere av slike forklaringer i de to siste tiårene. Et oppslag i VG kan tjene som et eksempel. Det slår fast at «guttehjernen henger etter» ${ }^{1}$ med utgangspunkt i en forståelse av hjernen som utelukkende biologisk konstituert. ${ }^{2}$

1 https://www.vg.no/nyheter/utenriks/i/11gj5A/gutter-boer-begynne-ett-aar-senere-paa-skolen

2 Hjerneforskningen går imidlertid i flere retninger. I boka The Gendered Brain argumenterer nevropsykologen Gina Rippon (2019) for at forskjeller mellom jenter og gutter som kommer til syne i skanningen av deres hjerner, må sees i lys av at de har blitt sosialisert inn i ulike kjønnsrollemønstre, smakspreferanser, handlingsrom 
Sæverot og Torgersen (2019) peker på at biologiske forklaringer er dominerende i Stoltenbergrapporten: NOU 2019: 3, Nye sjanser-bedre laring. Kjønnsforskjeller $i$ skoleprestasjoner og utdanningslop. Utvalgets leder Camilla Stoltenberg kan tolkes i samme retning når hun tar til orde for at:

Barn i ungdomsskolen fär karakterer som skal prege dem for livet mens de befinner seg $i$ helt ulike faser av puberteten og den biologiske «aldersforskjellen» mellom gutter og jenter er på sitt storste. Noen, sarlig jenter, er nesten utvokste, mens andre, sarlig gutter, knapt har kommet i stemmeskiftet. Hjernen er en del av kroppen og utvikler seg med den. Jenter fodt tidlig på året kan biologisk sett vere flere år «eldre» enn gutter fodt sent på året, likevel går de i samme klasse og måles mot hverandre (Stoltenberg 2017).

Man kan si at Stoltenbergs argumentasjon er preget av en svakt begrunnet kjønns- og menneskeforståelse basert på gruppekategorisering. Hvis pedagogikken og undervisningen skal bygge på så vidt grove kategorier, blir det dårlig, hevder Sæverot og Torgersen (2019). «'Modenheten' kan endres, begge veier, over tid i løpet av et langt skoleløp» (op.cit.). Det handler om at elevenes kjønnede kropper også er relasjonelt og sosialt konstituert, og at elevene selv også former sin forståelse av hva kjønn betyr for den enkelte (Engelsrud 2015). Det er vårt utgangspunkt i denne artikkelen.

NOU-en ble lagt til grunn for en etterfølgende Stortingsmelding (Meld. St. 6 [2019-2020]) om tidlig innsats i barnehage, skole og SFO. Den anbefaler en rekke tiltak. Deriblant en opptrapping av spesialpedagogiske tiltak for å giøre noe med kjønnsforskjellene i skoleprestasjoner og utdanningsløp som NOU-en avdekker. Når vi vet at $70 \%$ av de spesialpedagogiske tiltakene i den offentlige norske grunnskolen allerede er rettet mot gutter, kan man undre seg over om det å være gutt i skolen har blitt et spesialpedagogisk anliggende (Thaulow 2019).

NOU-en er basert på bortimot 800 vitenskapelige artikler og fagbøker som i hovedsak formidler evidensbasert forskning, dvs. forskning som baserer seg på metoder som har plass i evidenshierarkiet for gyldig kunnskap. I dette hierarkiet er det den tallbaserte årsak-virknings-forskningen som teller mest. Den normgivende gullstandarden for gyldig kunnskap er statistiske effektstudier med metaanalyser av veldefinerte, målbare forhold (Nielsen og Malterud 2019), og kun teori om kjønn som er basert på forskjell som biologisk. Kvalitative studier eller andre former for systematisert erfaringsbasert kunnskap inngår ikke i dette hierarkiet.

\section{Analytisk grep}

Vi vil i denne artikkelen se nærmere på grunnlagstenkningen som legger til rette for at denne forskningen kan fiksere gutter og jenter i posisjonen som enten

o.l. Denne forskningen er imidlertid ikke løftet fram i NOU-en som vi ser nærmere på i denne artikkelen. 
den Ene, eller den Andre som henger etter den Ene i skolen. Det gjør vi med utgangspunkt $\mathrm{i}$ et essay som har blitt kåret til en klassiker i norsk sosiologi: Dag Østerbergs Forståelsesformer fra 1966. Vi vil også ta tak i andre forhold mellom den Ene og den Andre enn kjønnsforholdet. På denne måten ønsker vi å gi artikkelen en videre tematikk. Betegnelsen den Andre er mye brukt i dag - ikke minst i tekster som er opptatt av etikk. Innenfor skolens rammer gjelder det spesielt $\mathrm{i}$ KRLE-faget (se f.eks. Eidhamar m.fl. 2007). Ofte mangler imidlertid en redegjørelse for forståelsen av forholdet mellom den Ene og den Andre, og noen ganger kan man få inntrykk av at bare begrepet 'den Andre' forekommer, så er argumentasjonen etisk (Nordtug 2013; 2014).

I siste del av artikkelen løfter vi fram en annen tilnærming til å utvikle kunnskap om den Ene og den Andre enn den evidensbaserte forskningen er grunnet i. Det er en tilnærming som inviterer til bevegelse og gjensidighet i forholdet mellom den Ene og den Andre, og som vi utdyper med utgangspunkt i begrepet participatory sensemaking. Selv om det er mange forskere som arbeider ut ifra en slik forståelse i dag, betraktes det ikke som gyldig kunnskap når evidenshierarkiets standarder legges til grunn.

Vi anvender den nevnte NOU-en og en rapport fra de årlige skolebaserte Ungdata-undersøkelsene (NOVA 2017) som eksempler på kunnskap om kjønnsforskjeller i skolen, som er basert på evidensbasert forskning.

\section{HVEM ER HVA I SKOLEN?}

Vogt, Sæverot og Torgersen reagerer på forskningsbaserte stillbilder av kjønnsforskjeller i skolen som fremstiller guttene som den Andre, i betydningen etter den Ene: jentene. Som enkeltpersoner med mannlig biologisk kjønn, gjør de motstand mot å identifisere seg med hvordan guttene på gruppenivå posisjoneres som den Andre i skolen. Og det er nettopp på gruppenivå og med utgangspunkt i det biologiske kjønnet NOU-en opererer. Ikke for å svartmale guttene eller for å sette dem i skolens skammekrok, men fordi «kjønnsforskjellene i utdanning er en samfunnsutfordring» (NOU 2019:3 s. 12). I innledningen setter NOU-en guttenes dårligere skoleprestasjoner og gjennomføring av utdanningsløpet i sammenheng med en rekke forhold hvor mennene kommer dårligere ut $i$ dagens norske samfunn. Det handler bl.a. om at menn oftere er kriminelle, får færre barn og at de dør tidligere sammenlignet med kvinner.

NOU-en fremlegger to årsaks-hypoteser som er forankret $\mathrm{i}$ et biologisk perspektiv. Den ene er utviklingshypotesen og den andre er sårbarhetshypotesen. Gutter er født både mer sårbare for miljømessige faktorer, òg de blir senere utviklet. I lys av Østerbergs (1966) forståelsesformer (som vi straks kommer tilbake til) kan man si at et slikt stillbilde lukker det biologiske kjønnet om seg selv og som et ledd $i$ et utvendig saksforhold til skoleprestasjoner og hurtighet i utdanningsløpet, samt metodene og teoriene som forskningen baserer seg på. 
Det er imidlertid ikke bare guttene som fikseres i posisjonen som den Andre i evidensbasert forskning om kjønnsforskjeller i skolen. Ungdatas avdekking av at jentene opplever mer stress og press i skolen enn guttene, og at de skårer høyere på indikatorene for psykiske helseplager, har fått mye oppmerksomhet. Et eksempel er et funn fra Ungdata-undersøkelsen i 2017 som har blitt gjentatt og gjentatt i mediene, av politikere, blant fagfolk og av andre som er opptatt av ungdom og psykisk helse; nemlig at «53 prosent av jentene og 26 prosent av guttene på tiende trinn i Oslo rapporterer om at de er ganske mye eller veldig mye plaget av psykiske helseplager» (NOVA 2017: 7). Det baserer seg på elevers avkrysning av 6 utsagn i et stort, digitalt spørreskjema i løpet av et par minutter (Nordtug og Engelsrud 2017). Lignende undersøkelser basert på den samme metoden har bekreftet Ungdatas funn (Sund, Rangul og Krokstad 2019) og slik bidratt til å forsterke stillbildet av jentenes dårligere psykiske helsemestring i skolen. Dette forskningsbaserte stillbildet har vært førende for hvordan andre kunnskapskilder, f.eks. kunnskap fra FHI om antall registrerte psykiske lidelses-diagnoser hos ungdom, har blitt fremstilt i forskningsrapporter og i mediene (Nordtug og Løkke 2020).

Selv om disse forskningsbaserte stillbildene posisjonerer jentene og guttene $i$ to ulike retninger med hensyn til hvem som er den Ene og den Andre i skolen, i betydningen hvem som er etter hvem, har de det til felles at de bygger på en forståelse av at den Ene og den Andre er lukket om seg selv i et utvendig forhold. Det gjelder både i forhold til hverandre og til det som undersøkes, og til selve undersøkelsen. Hva innebærer det at man forstår forholdet som utvendig? Vi skal utdype det med utgangspunkt i Østerbergs tre forståelsesformer.

\section{ØSTERBERGS TRE FORSTÅELSESFORMER}

Østerberg etablerer et skille mellom «tre forskjellige slags former for værender, nemlig utvendighet, identitet og innvendighet» (Østerberg 1966: 9). Når det gjelder utvendighet, skriver han at «En sak berøres ikke av det som er den utvendig, dvs. den forblir den samme hvordan det enn forholder seg med det som er den utvendig. Et utvendig eller ytre forhold mellom to saker (hendinger, gjenstander, værender) foreligger når hver enkelt av dem kan betraktes for seg, uavhengig av den andre, og er hva den er, hva enten den andre er eller ikke er» (Østerberg 1966: 9). Østerberg forbinder utvendighet med behovet vi mennesker har for å være sikker i en sak. Tvilen, beskriver han, er noe vi prøver å fri oss fra ved å falle tilbake på det sikre.

Det er det sikre den evidensbaserte forskningen søker seg mot. Sosiologen Ivar Frønes (2016) skriver at den evidensbaserte forskningen har fătt en så sentral plass i dag både i utdanningssammenheng (evidensbasert kunnskap), i arbeidslivet (evidensbasert praksis) og i politikken (evidensbaserte beslutninger) fordi vi lever $i$ en tid preget av stor usikkerhet. Samtiden er preget av høy endringshastighet og av risikoer som ikke kan forutsees fordi de er bivirkninger av vår egen virksomhet 
i et kunnskaps- og teknologisamfunn. Og det er nettopp sikring av påstander om kjønnsforskjeller i skolen den evidensbaserte forskningen brukes til i NOU-en. Fordi denne rapporten «skal gi lokale og nasjonale myndigheter et bedre grunnlag for å velge de mest effektive virkemidler og tiltak for å motvirke uheldige kjønnsforskjeller i skoleprestasjoner» (NOU 2019: 3 s. 27). Utvendighetstenkningen er imidlertid sammenhengsløs, i betydningen ikke-relasjonell og akontekstuell, påpeker Østerberg (1966: 18-20). Det må derfor andre forståelser til for at kunnskap skal kunne si oss noe om forholdet mellom den Ene og den Andre, og betingelser som dette forholdet beveger og beveges av.

Identitetstenkningen er imidlertid ikke en slik annen forståelse fordi den er så nært forbundet med utvendighetstenkningen. "Ved bestemmelsen av utvendighetsforholdet inngikk allerede begrepet om det samme, eller det identiske. Leddene $i$ et utvendig forhold er identiske med seg selv: De er hva de er, lukket om seg selv, uten noen henvisen til noe annet enn seg selv» (Østerberg 1966: 10). Et eksempel på en slik forståelse kan være når noen ønsker å skifte kjønn fordi de ikke føler seg som sitt biologiske kjønn. Kjønnsidentitet forstås da som et identisk forhold mellom biologisk kjønn og kjønnsfølelse. Men finnes det en spesifikk kjønnsfølelse? Sagt på en annen måte: er det mulig at kjønnsidentitet kan lukkes om seg selv i en kjønnsfølelse? Hvordan opptrer i så fall denne? Og vil det å føle seg som gutt eller jente være basert på samme gruppetenkning som vi så i den evidensbaserte forskningen? Dette er det pr. i dag lite utdypet kunnskap om. Det vedrører spørsmålet om identitetstenkning i forståelsen av forholdet mellom kjønn og biologisk kropp lukker for at valg av kjønn kan baseres på mer varierte kjønnsuttrykk enn det som griper endrende inn i en 'frisk' kropp ${ }^{3}$, som i stedet blir en 'feil' kropp som kjønnsfølelsen ikke stemmer med. I lys av Østerberg, er en slik forståelse med på å lukke for uttrykk, mer enn å åpne for å være gutt, jente eller hen på mindre inngripende måter.

Som alternativ til disse to forståelsesformenene, tar Østerberg til orde for en innvendighetsforståelse: «Med et innvendig eller indre forhold forstår jeg forholdet mellom to værender som begge er hva de er ved den andre. De viser gjensidig hen til hverandre» (Østerberg 1966: 10). En slik forståelse inviterer til å undersøke det bevegelige, gjensidige og tvetydige i forholdet mellom den Ene og den Andre enten det gjelder kjønnsforholdet eller andre forhold i skolen og på andre arenaer.

\section{ANDRE ANDRE}

Frønes (2013) belyser en annen forskjell i skolen enn kjønn; nemlig klasseforskjeller. Han hevder at skolen er innrettet etter middelklassens forstålsesformer. Dette skjer fordi det er middelklassen som er den dominerende kulturen i samfunnet vårt, skriver han. Hvis vi ser på det slik, kan man med Østerbergs

3 https://www.aftenposten.no/meninger/debatt/i/AKWWn/lurer-du-paa-om-du-er-transkjoennet-ikke-lesaviser-anki-gerhardsen 
(1966) forståelsesformer si at elevene og skolen står i et innvendig forhold til hverandre, der eleven med en annen klassebakgrunn nettopp blir den Andre i kraft av at skolen er innrettet etter den dominerende kulturen i samfunnet (den Ene). Det kan bidra til at elever og foreldre med en annen klassebakgrunn enn den som skolen er innrettet etter, ikke opplever at de hører hjemme i skolen, og dermed heller ikke engasjerer seg i det som skjer der.

Sosiologen og kjønnsforskeren Bjarne Øvrelid tar tak i dette i sin lesning av NOU-en. Han peker på at arbeiderklassegutter kan være i en slags opposisjon til skolen fordi - «Hvis kjonn kobles med arbeiderklasse, så kan guttene komme dårlig ut fordi den maskuline manifestasjonen som arbeiderklassegutter har blitt opplort til, altså det å vere litt reff, det å vaere fysisk aktiv, det å gjore ting istedenfor å lese ting og så videre, er ting som det ikke blir oppmuntret til eller som ikke fär noe relevans $i$ skolen» (Thaulow 2019: 49).

Både Frønes og Øvrelid er sosialisert inn i en ideologi-kritisk sosiologisk tradisjon, kan man si. I denne tradisjonen forbindes den Ene med dominerende verdisyn, ideologier og posisjoner som har makt, og den Andre med posisjoner hvor man ikke har de samme mulighetene til å tre fram med det egne. Det er imidlertid en fare for at en ensidig opptatthet av den Andres undertrykte posisjon ender opp i en utvendighetstenkning, hvor den Ene og den Andre ikke beveges av hverandre. Revolusjonen vil da bestå i at den Ene blir den Andre, og den Andre blir den Ene, uten noen form for gjensidig utvikling av forholdet dem imellom.

En lignende forståelse formidles hos filosofen Emmanuel Levinas (1997) $i$ hans analyser av det ureduserbare og ikke-gjensidige ansvaret for den Andre. Disse analysene har stor tilslutning i pedagogikkfaget i dag. Det gjelder spesielt undersøkelser av forholdet mellom læreren som den Ene, og eleven som den Andre (Nordtug 2013). Hos Levinas er det imidlertid bare den Ene som beveges og skifter posisjon i forholdet. I ansvaret for den Andre beveges den Ene av en Annethet hinsides væren som manifesteres i den Andres ansikt som en ikke-begripelig Annethet, og blir den som er etter den Andre. Den Andre forblir imidlertid en Annen. I denne bevegelsen hvor den Ene transformeres av den Andres Annethet og blir etter den Andre, konstitueres subjektiviteten. ${ }^{4}$

Filosofen Simone de Beauvoir tar i Det annet kjonn tak i et resonnement hos Levinas i hans essay om Tiden og den Andre. Levinas beskriver her det kvinnelige som det som av seg selv er Annet. Hun skriver at: «Det er slående at han [Levinas] med vitende og vilje inntar en mannlig synsvinkel uten å gjøre oppmerksom på gjensidigheten mellom subjekt og objekt» (Beauvoir 2000: 36). Levinas tar ikke høyde for den generaliserte Andre (for å bruke George Herbert Meads begrep) som Beauvoir (2000) i dette sitatet knytter til Levinas' kjønnede blikk. Den

4 Hvis man anvender Levinas' analyser på læring, som også har et aspekt av overskridelse ved seg gjennom at man lærer noe nytt, kan man si at det bare er læreren som lærer i relasjonen til eleven som den Andre. 
generaliserte Andre kan også manifesteres i et blikk som er preget av middelklassens verdisyn, slik Frønes og Øvrelid løfter fram. Og det kan være et blikk preget av forskningsbaserte stillbilder av kjønnsforskjeller i skolen, slik vi har pekt på.

Det er også verdt å merke seg at Levinas ikke tar høyde for psykoanalysens ide om die anderen Schauplatz: den annen skueplass; det ubevisste, som påminner oss om vår irrasjonalitet og tilkortkommenhet $\mathrm{i}$ ansvaret for den Andre (Derrida 2002: 38). Når Levinas' analyser anvendes på lærer-elev-forholdet, er det derfor en tendens til at den Enes ansvar for den Andre beskrives som langt mer uselvisk enn slik det er i praksis (Nordtug 2013). Med Beauvoirs formulering kan man si at det er slående at Levinas' tenkning er så mye brukt i analyser av lærer-elevforholdet.

\section{Å BEVEgES AV HVERANDRE}

Ulike grupper og enkeltindivider kan se på skolen på ulike måter. Hvis skolen lar seg bevege av disse ulike måtene, kan det skje en utvikling av skolens selvforståelse. Det kan igjen bevege elevenes opplevelser av hva skolen inviterer til og gir muligheter for. Man kan da med Østerbergs (1966) innvendige forståelsesform si at elevene og skolen står $i$ et forhold til hverandre, der de gjensidig utvikler hverandre. Slik kan man også tenke seg at jenter og gutter kan endres og utvikles i skolen på en gjensidig måte. Det løftes imidlertid ikke fram i de forskningsbaserte stillbildene i NOU-en og i Ungdata fordi denne forskningen er grunnet i en utvendighetstenkning. Å basere seg på en slik forståelse i forskning, reproduserer den forståelsen av gutter og jenter som innenfor dette paradigmet får status som sikker kunnskap, og som dermed fortsetter å bli tatt for gitt.

I klassikeren Mytologier knytter Roland Barthes slike tatt-for-gittheter til hvordan myten jobber i meningsskapingen i og mellom oss i ulike sammenhenger. Han skriver om myten at den «på en eller annen måte smyger seg inn gjennom naturens bakdør. Det er av denne grunn myten oppleves som en uskyldig ytring: ikke fordi den skjuler sine intensjoner: hvis de virkelig var skjult, kunne de ikke ha noen effekt; men fordi de blir naturalisert» (Barthes 1975: 186). Han skriver videre at myten presenterer en verden uten dybde og kompleksitet. Det er nettopp en slik verden utvendighetstenkningen i forskningen avdekker, og det er langt ifra livene slik de leves og har ulike betingelser, når det gjelder både klasse og kroppsforståelser.

\section{EN ANNEN KUNNSKAPSTILNÆRMING}

Aasland (2018) tar til orde for at kjønn i steinerpedagogikken kan knyttes til en forståelse av at sjelen er kjønnsløs i sin karakter, og at individet må integrere både det kvinnelige og det mannlige i seg selv gjennom dannelse og opplæring. Det harmonerer med skapelsesberetningens ord om at «de to skal være én kropp» 
(1. Mosebok, 2.24). Overført til forskning på kjønnsforskjeller i skolen, inviterer en slik forståelse til å undersøke forholdet mellom jenter og gutter som et mellommenneskelig forhold der den enkelte er ved den andre og begge er innvevd i hverandre og i verden.

Filosofen Hanne de Jaegher (2019) peker på at mye forskning gir lite kunnskap om det som den enkelte er opptatt av i den sammenhengen som vedkommende lever i. Forskningen må derfor i større grad skape kunnskap om det som den enkelte interesserer seg for. Hun tar til orde for en tilnærming som hun relaterer til begrepet participatory sensemaking. Det handler om at kunnskap skapes mellom mennesker som konkret interesserer seg for hverandre. I et slikt perspektiv blir det viktig å få fram betydningen av en grunnleggende og direkte måte å være i verden på: å komme tett på det som gjelder og dem det gjelder. Forskning grunnet i en slik tilnærming baserer seg på at «den umiddelbare kjensgjerning frembyr et indre forhold mellom det begrepne og det sansede» (Østerberg 1966: 71).

Innvendighetstenkningen og begrepet participatory sensemaking inviterer videre til å delta i hverandres liv og intersubjektivitet uten å være redd for å miste egen subjektivitet, og her kjønnsidentitet. Her blir kjønn noe som kan utforskes $i$ samspill mellom mennesker og ved å engasjere seg i egen kroppslig subjektivitet $\mathrm{i}$ samspill med andre. Kjønn blir slik sett et relasjonelt begrep. Ord vi henviste til i innledningen som at gutter svartmales og kategoriseres på gruppenivå, gir dermed snevre rammer for hvem de kan være og stillbildet åpner kun for å ta en posisjon som enten den Ene eller den Andre.

Hvis vi tar tilnærmingen som Hanne de Jaegher (2019) tilbyr på alvor, betyr det å engasjere seg, slik Simone de Beauvoir gjorde, og å sette mennesker før kjønn. Selv om kjønn er viktig, så er likhetstrekk på gruppenivå ikke en fruktbar posisjon for dagens pedagogikk og skolepolitikk. Gyldig kunnskap kan ikke avgrenses til forskningsmetoder som har plass i evidenshierarkiet, men må også omfatte erfaringsbasert kunnskap og kvalitativ forskning med et førstepersonsperspektiv. Med et slikt perspektiv, blir det tydelig at kjønn i skolen leves, og at det innebærer et mangfold av erfaringer som handler om mye mer enn karakterer og gjennomstrømmingshastighet i utdanningsløpet og indikatorene som Ungdata bruker. 


\section{LitTERATUR}

Barthes, R. 1975. Mytologier. Gyldendal.

Beauvoir, S. de. 2000. Det annet kjønn. Pax forlag.

Derrida, J. 2002. ADJØ til Emmanuel Levinas. Cappelen Akademisk Forlag.

Eidhamar, L.G., Leer-Salvesen, P., Hølen, V. 2007. Den Andre-etikk og filosofi i skolen. Høyskoleforlaget.

Engelsrud, G. 2015. Kjønn og inkludering. I: Førland Standal og Rugseth (red.). Inkluderende kroppsøving. Cappelen Damm.

Frønes, I. 2013. A forstå sosialisering. Gyldendal Akademisk.

Frønes, I. 2016. Høyterskelsamfunnet. I: Frønes, Eng, Ertesvåg og Kjøbli (red.). Risiko, intervensjon og evidens (s. 110-126). Gyldendal Akademisk.

Jaegher, H. de. 2019. Loving and knowing: reflections for an engaged epistemology. Phenomenology and the Cognitive Sciences. https://doi.org/10.1007/ s11097-019-09634-5

Levinas, E. 1997. Otherwise Than Being or Beyond Essence. Kluwer Academic.

Meld. St. 6 (2019-2020). Tett på-tidlig innsats og inkluderende fellesskap i barnehage, skole og SFO. Departementenes sikkerhets- og serviceorganisasjon. Teknisk redaksjon.

Nielsen, H.B. og Malterud, K. 2019. Kunnskap for politikk og praksis? En analyse av Stoltenbergutvalgets kunnskapssyn. Tidsskrift for Samfunnsforskning, 60 (3), s. 274-284.

Nordtug, B. 2013. The welcoming of Levinas in the Philosophy of Education At the cost of the Other? Theory and Research in Education, 11 (3), s. 250-268. http://dx.doi.org/10.1177/1477878513498174

Nordtug, B. 2014. Levinas's ethics as a basis in healthcare - challenges and dilemmas. Nursing Philosophy. 16 (1), s. 51-63. https://doi.org/10.1111/ nup. 12072

Nordtug, B. og Engelsrud, G. 2017. Fysisk aktivitet for bedre psykisk helse - noen betraktninger. Bedre Skole. 29 (4), s. 28-33.

Nordtug, B. og Løkke, P.A. 2020. Når det er tallene som teller. Kunnskap om ungdom og psykisk helse $\mathrm{i}$ et byråkratisk positivistisk landskap. Fontene forskning. 13 (1), s. 89-95.

NOU, Norges offentlig utredninger (2019:3). Nye sjanser - bedre laering. Kjønnsforskjeller i skoleprestasjoner og utdanningsløp. Departementenes sikkerhetsog serviceorganisasjon. Teknisk redaksjon.

NOVA. 2017. Stress og press blant ungdom: erfaringer, årsaker og utbredelse av psykiske helseplager. NOVA-rapport 6/17. NOVA.

Rippon, G. 2019. The Gendered Brain. The new neuroscience that shatters the myth of the female brain. Vintage Publishing. 
Stoltenberg, C. 2017. Vi har skapt et nytt kjønnsgap før vi har rukket å kvitte oss med det gamle. Morgenbladet. 10.02.2017.

Sund, E.R., Rangul, V. og Krokstad, S. 2019. Folkehelseutfordringer $i$ Trondelag. Folkehelsepolitisk rapport med helsestatistikk fra HUNT inkludert tall fra HUNT4 (2017-19). HUNT forskningssenter og Institutt for samfunnsmedisin og sykepleie, NTNU.

Sæverot, H. og Torgersen, G.-E. 2019. Stoltenbergutvalget mangler pedagogisk innsikt. Dagbladet. 06.03.2019.

Thaulow, B. 2019. Kjønn i spesialpedagogisk politisk utviklingsarbeid: en resepsjonsanalyse av NOU 2019:3 - Nye sjanser-bedre loering. Kjonnsforskjeller $i$ skoleprestasjoner og utdanningsløp. Masteroppgave i spesialpedagogikk. Høyskolen i Innlandet, Lillehammer.

Vogt, K.C. 2018. Svartmaling av gutter. Norsk sosiologisk tidsskrift. 2 (2), s. 177-193. https://doi.org/10.18261/issn.2535-2512-2018-01-06

Østerberg, D. 1966. Forståelsesformer. Gyldendal.

Aasland, A. H. 2018. Har steinerpedagogikken blikk for kjønn? Steinerbladet. 2018/\#2. 